\title{
ASSESSMENT OF HEALTH BEHAVIOUR OF SCHOOL-AGE YOUTH
}

\section{OCENA ZACHOWAŃ ZDROWOTNYCH MŁODZIEŻY SZKOLNEJ}

\author{
${ }^{1}$ Ludwik Rydygier Medical University of Bydgoszcz, Nicolaus Copernicus University in Torun, \\ The Departament of Rehabilitation \\ ${ }^{2}$ School of Humanities-Economics in Wloclawek
}

\section{S u m mary}

Introduction. Adolescence is a very important period for young people as it is the time when the patterns of health behaviour stabilize and in such form may be adopted for the rest of one's life. This age group is also most prone to behaviour posing a risk to health and lacking behaviour good for health. The period of education is the most suitable to make teenagers aware of how much depends on themselves. Adolescence is often the time of rebellion and independent decision making which influence both the diet, way of spending fee time, personal and mental hygiene as well as abusing dangerous substance. The aim of the study was to assess the health behaviour of lower secondary school attendees in the scope of diet and physical activity by means of a questionnaire. The materials were based on research regarding health behaviour. The study group consisted of 90 students $(60 \%$ male, $40 \%$ female). A questionnaire was chosen as the study method. The study was performed in 2012, from May until September. The results were comparable with HBSC results from 2006 in which $64.4 \%$ of the adolescents did not achieve the recommended physical activity minimum. The research has shown that adolescents prefer passive ways of spending their free time. Studies which monitor the state of behaviour linked with the health of the youth are carried out both internationally, nationally and locally. Poland achieves poor results in comparison to other countries when it comes to level of physical activity and amount of time spent on passive leisure.

\section{Streszczenie}

Okres dorastania jest bardzo ważny dla młodzieży, ponieważ stabilizują się wzory zachowań zdrowotnych, które w utrwalonej formie mogą towarzyszyć człowiekowi przez całe życie. Dorastająca młodzież jest najbardziej narażoną grupą społeczeństwa na występowanie zachowań ryzykownych dla zdrowia i niedostatki w zakresie zachowań dla zdrowia korzystnych. Etap edukacji to najlepszy moment na uświadomienie nastolatkom, jak wiele zależy od nich samych. Młodzież w okresie dojrzewania przeżywa często czas buntu i podejmowania samodzielnych decyzji, ma wpływ na samodzielny sposób odżywiania się, spędzania wolnego czasu, higienę osobistą, higienę umysłowa, czy decydując sięganiu po różnego rodzaju używki. Niekorzystne dla zdrowia zachowania prowadzić mogą do wielu chorób somatycznych w tym np. chorób układu sercowo-naczyniowego czy nowotworowych będących najczęstszymi przyczynami umieralności. Kształtowanie prozdrowotnych zachowań młodzieży jest więc niezwykle istotne dla budowania potencjału zdrowotnego przyszłych pokoleń. Dlatego też realizacja treści prozdrowotnych ma pomóc w przekazaniu zasobu wiedzy teoretycznej o zdrowiu, pozwala ukształtować postawę człowieka zainteresowanego własnym zdrowiem i dbającego o nie.

Key words: health behaviour, lower secondary school, lifestyle, physical activity

Słowa kluczowe: zachowania zdrowotne, gimnazjaliści, styl życia, aktywność fizyczna 


\section{AIM OF THE STUDY}

The aim of the study was to analyse the health behaviour of lower secondary school students in the scope of their diet, physical activity and means of spending their free time, as well as getting to know the demographic inter-relations between the aspects mentioned above, sex and age.

\section{INTRODUCTION}

According to the authors, health is an abstract term which is also hard to define. Musings on health and its concept make up a part of medical and social sciences such as: psychology, sociology and health pedagogics. It is also one of the subjects of the health and health promotion sciences. Each of the aforementioned disciplines has a unique perspective on health and analyses different aspects of it $[1,6,25]$.

The definition of health presented by WHO constitution states that health is a state of complete physical, mental and social well-being and not merely the absence of disease or infirmity. According to this definition, health is a state of full well-being in several aspects (physical, psychological and social) and it is subject to subjective assessment by means of one's self-feeling [12].

\section{HEALTH DETERMINATES ACCORDING TO LALONDE'S FIELDS}

The most significant (53\%) influence on human health is held by person's lifestyle which includes such elements as: physical activity, diet, the ability to deal with stress, using stimulants (nicotine, alcohol, psychoactive drugs) and sexual habits. Environment holds about $21 \%$ of the influence. Pollution free air and water, a safe school and friendly workplace have a positive influence on health. The negative influence of the environment is mostly linked with its degradation, ionizing radiation, noise, harmful chemical substances and biological factors. In $16 \%$ human health is determined by genetic factors. They may cause genetic predispositions for some diseases or cause specific health issues. Only $10 \%$ of human health is based on healthcare, its structure, organization, functioning and access to basic medical services and their quality. There are multiple factors influencing human health and they may interact. The only exception are the genetic factors which may have both a direct and indirect influence. Direct determinants are: diet and addictions. Indirect determinants are macroeconomic or socio-demographic factors. They have a significant influence, positive or negative, on the direct factors [29].

\section{HEALTH BEHAVIOUR}

Health behaviour is defined as activity which intentionally aims at health. The human conviction regarding the influence of a given behaviour on health is the deciding factor. Health behaviour is defined, among others, by I. Heszen-Klemens who uses the 'health actions' term and describes them as 'all forms of purposeful activity which are aimed at protecting of bettering of one's health' [7]. The character of the behaviour is also shown by Z. Juczyński who describes it as 'such personal attributes as beliefs, expectations, motivations, observations and other cognitive elements, elements of character, including emotional traits and states, overt behavioural patterns, actions and habits which are linked with keeping, regaining and improving one's health' [9]. Such a broad approach to the topic of health behaviour underlines not only the behavioural aspect but also the awareness of the individual as well as its expectations and personality. The group of effect definitions concentrates on the positive or negative effects of behaviours. In this view, health behaviours are behaviours which have proved negative or positive influence on health [15]. Thus, two basic groups may be defined: pro-health and antihealth. Health behaviours are defined on the basis of objective knowledge linked with the relation to health. The differentiation of the links of behaviour with health is shown by the definition of A. Frączka and E. Stępień who describe them as "such activities taken up and realized by humans which:

- directly and immediately or indirectly and in the long-term aid or harm the keeping of normative physical and/or mental health standards;

- are shaped as a result of the socializing experiences of the individual, especially through the interaction with the immediate social surroundings;

- are common enough or mass that they are a social and not an individual problem" [3].

Another type of health behaviour definition tries to merge all of the above definitions. K. Puchalski proposed to join the purposeful and effect definitions 
and defined them as 'behaviours (or types of behaviours) chosen by the observed or the subject which based on a certain knowledge system (for example: common knowledge, a given scientific concept, social ideology, etc.) remain in a significant and defined by this option relation to health the meaning of which is determined by this system of knowledge' [15]. A similar way of presenting health behaviours is used by I. Sęk, who defines them as: 'reactive, habitual and/or purposeful forms of activity which remain - on the basis of objective health knowledge and subjective beliefs - in significant, mutual relationship with health' [20].

\section{TYPES OF HEALTH BEHAVIOUR}

The criteria of health behaviour classification:

1. The function of behaviour in relation to health positive or negative assessment.

2. The level of behavioural organisation - describing the habit or activity.

3. The level of awareness and aim of the behaviour.

4. The health level in relation to which the behaviour is carried out.

5. Health behaviour linked with one's social role.

6. The content of the behaviour, sphere of life and activity [6].

Taking into consideration the abovementioned criteria we can differentiate pro-health behaviours, which improve health and prevent diseases (for example: a balanced diet, physical activity) and antihealth behaviours which harm one's health, have a negative impact and may lead to diseases (for example: smoking, excess alcohol consumption) $[6,20]$.

\section{LIFESTYLE AND HEALTH}

Lifestyle is a term which is often used but is understood differently by social and medical sciences. It is the illustration of the functioning of an individual or a group. An individual's lifestyle may strengthen his or her health potential or develop negative tendencies. In psychology it is understood as 'a system of health behaviours characteristic for an individual and conditioned by temperament, knowledge, general opinions and beliefs regarding the world, life and himor herself, competences, belief system and sociocultural variables' [20]. When analysing the link between lifestyle and health, we describe it as 'pro- health lifestyle', 'healthy (or not) lifestyle', 'lifestyle beneficial to health'. The pro-health lifestyle means aware, purposeful actions which are linked with increasing the potential of one's health and the elimination of the negative behaviours which endanger health [26]. At this point, the link between health and four basic behaviours (diet, smoking, alcohol and physical activity) is the best documented in research $[11,14,19,28,26]$.

\section{DIET}

The results of recent studies point to a relation between one's diet and physical and mental development and the well-being of a person. By rational dieting we understand eating products which supply the organism with both the optimal amount of energy and nutritional elements in proper proportions and with a proper frequency [22]. Efficient usage of the nutrients depends largely on how regularly the meals are consumed. It is best to consume them at the same, regular times. Dividing the daily ration into 4-5 meals with breaks not longer than 4 hours is considered the most rational. When the meals are consumed less often, the glucose level decreases. This causes a feeling of tiredness, makes concentration harder and thus, make it difficult to work or study. Breakfast should provide about $20-25 \%$ of daily demand, lunch $35-40 \%$ and the remaining meals $35-45 \%[23,30]$.

\section{PHYSICAL ACTIVITY}

Physical activity is a basic, biological need of the human being. The point is in physical effort which is linked with the activity of skeletal muscles and the accompanying complex of functional changes in the organism and the energy usage. Physical activity is linked with different behaviours which are related to everyday life activities, locomotion, studying, professional work, recreation and practicing sports. Sedentary behaviours are opposed to physical activity. They are characterized by a lack of movement or minimal intensity of the movement, so they are: reading, watching TV or working at the computer [16].

\section{THE FUNCTIONS OF PHYSICAL ACTIVITY IN DIFFERENT LIFE PERIODS}

During the period of childhood and puberty physical activity has the following functions: 
1. Stimulation and supporting development:

- physical - it stimulates body growth, helps muscles development;

- motoric - improves physical fitness and motoric abilities;

- intellectual - enables for the recognition of the surroundings, items and phenomena;

- psychological - it creates situation in which we must learn to overcome difficulties, deal with tiredness, control our emotions, go through success and failure;

- social - helps building relations with other people and teamwork abilities.

2. Adaptation to different stimuli and changes taking place in the physical and social surroundings.

3. Compensating for the negative phenomena of modern life.

4. Preventing developmental and health disorders like obesity, disorders of the motoric system and preventing osteoporosis and arterial sclerosis.

5. Disorder therapy - obesity, diabetes, asthma, activity system disorders, body posture disorders and many other diseases [4].

During adolescence and adulthood physical activity prevents many diseases and it slows down the aging process. It has been proven that physical activity lowers the risk of ischaemic heart disease, cardiovascular diseases, type 2 diabetes, osteoporosis, hypertension, metabolic disorders and even some tumours. Taking part in any form of physical activity helps keeping the right body mass and lowers the risk of obesity. The beneficial influence of physical activity has also been noted in case of psychological and neurological disorders such as: fear states, depression, sleep disorders and even Parkinson's and Alzheimer's diseases [5, 18, 24]. Spontaneous physical activity and the need for movement change in particular periods of human life. In childhood (the time from birth until about 10 years of age) the child is very active and needs a lot of movement. Physical activity is mostly linked with playing, learning and discovering the world. During adolescence the progression into an adult form of physical activity takes place. This means a change in its form, aim and motivations. The most important change is the gradually increasing drop in the level of physical activity. The drop is more significant when it comes to girls. A lack of need for any form activity around the time of the first period is a typical phenomenon. At this time visible, sexdependent differences in motivation start to appear.
Boys want to stay in shape and girls want to look good. Girls are rarer to undertake physical activity in adverse conditions. In adulthood the level of activity drops gradually and it is especially visible when it comes to women. A low level of physical activity is true for 50$60 \%$ of adults. Old age means a worrying aversion to movement and a significant drop in physical activity [24, 25]. Many factors influence one's physical activity. It is commonly thought that the dominant factors are psychological, social and environmental. There is a biological control of the spontaneous physical activity level. Those are mechanisms the role of which is to control the energy output in order to keep the energetic balance as well as stable body mass. This need was shaped in the prehistoric times in order to save energy for periods of low nourishment. Currently this mechanism has been distorted by overeating and a sedentary lifestyle as well as factors of psychological nature which appear more and more often. This leads to obesity or, on the other hand, anorexia. An optimal level which secures biological and health needs is dependent on age, life conditions and current state of health. Many countries have developed recommendations which are linked with physical activity in different age groups. The following elements are taken into considerations in those recommendations:

- total time of physical activity - that is the sum of the time of all forms of physical activity in everyday life, professional work, recreation as well as during physical effort and sports training,

- intensity of the effort which is defined using the types of activities and the measuring of different physiological factor, for example: heart rate [24].

Sixty minutes are the time of physical activity recommended to adults and adolescents. Moderate physical activity is the most recommended and it can be: biking, gymnastics without weight training, working in the garden, swimming or taking a walk [8]. Physical activity is a key and integral element of prohealth lifestyle and it is especially important for children and adolescents. It is necessary for the proper development and for physical, psychological and social health. Regular physical activity which follows the recommendations has a positive influence on the development and growth in childhood and adolescence. It also helps keeping good health and endurance in adulthood. Limiting everyday physical activity, which is linked with the spread of civilisation, is a real and serious threat to human health. Low or the lack of 
activity of the young leads to overweightness and obesity. This is linked to the popularity of sedentary lifestyle and spending many hours in front of the TV or computer. A radical drop in endurance and fitness, an increase in locomotor disorders and bad posture can be an example of the influence of the lack of physical activity [4].

\section{MATERIALS AND METHODS}

In order to assess the health behaviour of adolescence a study was performed amongst lower high school students. The material was based on scientific findings related with the assessment of health behaviour. The study group consisted of 90 students (60\% male, $40 \%$ female). A questionnaire was chosen as the study method.

\section{RESULTS}

Significant abnormalities were noticed in the number of sweets, fruit, vegetables, while diary, grain and meat products were discovered. Sweets were consumed by $92 \%$ of the respondents and by $11 \%$ more than 3 times a day. Fruits were consumed more than 3 times a day only by $8 \%$ of the students and $40 \%$ of them admitted that they only eat fruit once a day. Similarly, dairy, grain and meat products were consumed once per day by as much as $63 \%$.

The assessment of sex differences when it comes to health behaviours.

The sex of the respondents influenced the behaviour linked with the presence of sweets, fruits, vegetables and dairy products. Girls eat sweets more often than boys. Only $2 \%$ of the girls fully resigned from eating sweets at all. But girls eat more fruit and vegetables $-16 \%$ of girls and only $2 \%$ of boys eat at least three times a day. When it comes to consuming dairy, grain and meat products $38 \%$ of girls and $25 \%$ of boys ate them only once a day. The age of the respondents did not have a significant influence on their behaviours when it comes to sweets, fruit, vegetables, as well as grain, dairy and meat products consumption. The study group also showed issues with the number of meals per day. Most of the students admitted eating only 3 meals a day. When asked to analyse their own healthy diet, the students mostly did not know whether their diet is healthy or not. A significantly lower level of physical activity has also been noted. $30 \%$ of the respondents spend only an hour of their time free from school and games. Almost 5\% did not take part in any physical activity. The respondents grade their physical effort as medium. Significant abnormalities were also shown when it comes to spending time in front of the TV or computer. $21 \%$ of students spend over 3 hours a week watching $\mathrm{TV}$ or in front of the computer. The study shows that sex has no influence on the number of hours spent on physical exercise. The age of students has no impact on their physical activity but it does influence leisure time activities. The 15-16 year-olds should spend less time in front of the TV or the computer.

\section{DISCUSSION}

The studies which monitor the state of health behaviour of the adolescents are carried out internationally, nationally and locally. They are linked with the proliferation of positive behaviours and of the harmful ones. Every four years Poland takes part in integration questionnaire regarding health and health behaviour of students aged 13-16. This program is carried out with the help of the European Bureau of WHO. The project is called Health Behaviour in School - aged Children. At this point a technical report from the Polish studies is available as well a report in English which talks about all of the European and North American countries which took part in this study. In the international report the results of the study by HBSC have been put in four groups: social aspect of health, health itself, positive health behaviours and the negative ones. Adolescents from Poland are usually placed in the middle of the table when it comes to the tested variables. There are also markers which can be either positive or negative. One statistic that is very favourable for Poland is the low number of injuries requiring medical attention and a low numbers of children who are over-weight or obese. The negative aspects are low physical activity level and too much time spent on computer games and the early age at which alcohol is consumed for the first time [5]. According to the 2006 HBSC report $64.4 \%$ of students do not reach the minimum physical activity threshold. What is more, during school days, $39.8 \%$ of students watch 3 or more hours of TV, $32.2 \%$ plays PC or console games for 2 hours and more than a half used the computer for goals different than studying. Those numbers rise significantly during the weekends. More than a half (two thirds during the weekend) of boys spend too much time on computer games. Also, small, 
regional studies have been carried out The study carried out in Gorzów Wielkopolski in which 1263 students took part showed that $57 \%$ of the students do exercise less than 4 times a week. At the same time $51 \%$ of the respondents spend 4 or more hours watching TV and many other students in front of the computer. Sex differences highlight the possible future changes. Boys spent a lot more time on physical activity: 4 hours more per week $-45.1 \%$ of boys and $30.5 \%$ of girls exercise. Boys and girls spend a similar amount of time on watching TV. When comparing the aforementioned results with the studies performed on a different group of adolescents, one can say that low physical activity is too common. At the same time the studies did not show any link between sex and age and the level of physical activity. They have also shown that adolescents prefer passive forms of resting as well as pointed to the significant influence of sex and age on the ways free time is spent. Students aged 15-16 would prefer to spend more time on watching TV and playing computer games. There are also many abnormalities when it comes to dieting. Fresh fruit and vegetables are consumed by $41.7 \%$ of students of the lower secondary school, milk and dairy products are drank every day by $46 \%$ of students and sweets are eaten everyday by $38.2 \%$ of the respondents. The sex of the respondents influences their diet. Girls eat fruits and vegetables more often than boys but they eat too much sweets. When it comes to the diet, age had a significant influence only when it comes of eating fruits and vegetables [22]. In the group of lower secondary school students significant abnormalities were noticed when it comes to the number of meals consumed per day. This phenomenon shows that education is needed in this regard.

\section{CONCLUSIONS}

According to the 2006 HBSC study $64.4 \%$ of students do not reach the minimum activity threshold. Sex determines behaviours linked with physical activity. One can notice a negative relation between low physical activity with high frequency. Anti-health behaviours may lead to somatic diseases cardiovascular diseases and tumours which are the most common reasons of death. Shaping pro-health behaviours of the youth is important when it comes to building up the potential for future generations. That is why the realization of pro-health contents should help in transferring the state of the theoretical health knowledge, allow shaping the attitude of a person interested in one's health and caring about it.

\section{REFERENCES}

1. Blaxter M.: Okła M.(tłum.).: Zdrowie. Wydawnictwo Sic!, Warszawa 2009

2. Currie C. i wsp.: Inequalities in young peoples health: HBSC international report from the 2005/2006 survey. WHO Regional Office for Europe, 2008

Tekst uzyskany dnia 10.05.2013 roku ze strony http://www.euro.who.int

3. Frączek A., Stępień E.: Zachowania związane ze zdrowiem wśród dorastających a promocja zdrowia [w:] Ratajczak Z., Heszen- Niejodek I. (red.).:

Promocja zdrowia. Psychologiczne podstawy wdrożeń. Wydawnictwo Uniwersytetu Śląskiego, Katowice 1997, 70-76 ( op. cit., str. 70-71

4. Drabik J.: Aktywność fizyczna dzieci, młodzieży i dorosłych. Akademia Wychowania Fizycznego w Gdańsku, Gdańsk 1995

5. Gniazdowski A.: Zachowania zdrowotne a zdrowie. Badanie związków [w:] Gniazdowski A. (red.).: zachowania zdrowotne. Wydawnictwo Instytutu Medycyny pracy, Łódź 1990, 83-129

6. Heszen I., Sęk H.: Psychologia zdrowia. Wydawnictwo Naukowe PWN, Warszawa 2007

7. Heszen-Klemens I.: Psychologia medyczna. Główne kierunki badań. Wydawnictwo Uniwersytetu Śląskiego, Katowice 1983 (op. cit., str.97)

8. Januszewicz P., Szymborski J.: Aktualne problemy w opiece nad dzieckiem w Polsce- kierunki rozwiązań systemowych [w:] Januszewicz P., Szymborski J.(red.).: Zdrowie naszych dzieci. Zakład Zdrowia Publicznego i Medycyny Szkolnej Instytutu Matki i Dziecka, Warszawa 2001, 15-25

9. Juczyński Z.: Przekonania i oczekiwania wyznacznikami zachowań związanych ze zdrowiem [w:] Juczyński Z., Ogińska-Bulik N. (red.).: Zasoby osobiste i społeczne sprzyjające zdrowiu jednostki. Wydawnictwo Uniwersytetu Łódzkiego, Łódź 2003, 49-61 (op. cit., str. 49)

10. Kołoło H.: Aktywność fizyczna [w:] Mazur J. (red.).: Status materialny rodzin i otoczenia a samopoczucie i styl życia młodzieży 15-letniej. Wyniki badań HBSC 2006 w ujęciu środowiskowym. Instytut matki i Dziecka, Warszawa 2007, 59-63. Tekst uzyskany dnia 10.05.2013 roku ze strony http://www.imid.med.pl

11. Kosińska M. (red.).: Styl życia dla zdrowia. Wydawnictwo Beskidzkiej Wyższej Szkoły Umiejętności, Żywiec 2006

12. Kulik T., Latalski M.: Zdrowie publiczne. Podręcznik dla studentów i absolwentów wydziałów pielęgniarskich i nauk o zdrowiu akademii medycznych. Wydawnictwo Czelej, Lublin 2002, 15-33

13. Mazur J., Woynarowska B., Kołoło H.: Zdrowie subiektywne, styl życia i środowisko psychospołeczne młodzieży szkolnej w Polsce. Raport techniczny z badań 
HBSC 2006. Instytut matki i Dziecka, Warszawa 2007 Tekst uzyskany dnia 10.05.2013 roku ze strony http://www.imid.med.pl

14. Ostrowska A.: Styl życia a zdrowie. Wydawnictwo Instytutu Filozofii i Socjologii PAN, Warszawa 1999

15. Puchalski K.: Zachowania związane ze zdrowiem jako przedmiot nauk socjologicznych. Uwagi wokół pojęcia [w:] Gniazdowski A. (red.).: Zachowania zdrowotne. Wydawnictwo Instytutu Medycyny Pracy, Łódź 1990, 23-57 (op. cit., str. 56)

16. Raczek J.: Antropomotoryka. Teoria motoryczności w zarysie. Wydawnictwo Lekarskie PZWL, Warszawa 2010

17. Rowland T.W.: Childrens exercise physiology, Human Kinetics, USA 2005

18. Scheridan Ch.L., Radmacher S.A.: Psychologia zdrowia. Wyzwanie dla biomedycznego modelu zdrowia. Instytut psychologii zdrowia, Polskiego Towarzystwa Psychologicznego, Warszawa 1998

19. Siciński A.: Styl życia. Kultura wyboru. Wydawnictwo Instytutu Filozofii i Socjologii PAN, Warszawa 2002

20. Sęk H.: Zdrowie behawioralne [w:] Strelau J. (red.).: Psychologia. Podręcznik Akademicki.. Jednostka w społeczeństwie i elementy psychologii stosowanej, t.3. GWP, Gdańsk 2000, 533-553 (op. cit., str. 539, str. 543)

21. Świderska-Kopacz J., Marcinkowski J., Jankowska K.: Zachowania zdrowotne młodzieży gimnazjalnej i ich wybrane uwarunkowania. Cz. IV. Sposób żywienia. Problemy higieny i epidemiologii. 2008, 89 (2), 241-245

22. Świderska-Kopacz J., Marcinkowski J., Jankowska K.: Zachowania zdrowotne młodzieży gimnazjalnej i ich wybrane uwarunkowania. Cz. V. Aktywność fizyczna. Problemy higieny i epidemiologii. 2008, 89 (2), 246-250
23. Turlejska H.: Rola żywienia w życiu człowieka. Roczniki Państwowego Zakładu Higieny 2000, 2, 218-244

24. Ward D.S., Saunders R.P., Pate R.R.:Physical activity inervention In children and adolescents, Campaing, Human Kinetics, USA 2007

25. Woynarowska B., Kowalewska A., Izdebski Z., Komosińska K.: Biomedyczne podstawy kształcenia i wychowania. Podręcznik akademicki. Wydawnictwo naukowe PWN, Warszawa 2010, 188-246

26. Woynarowska B.: Edukacja zdrowotna. Podręcznik akademicki. Wydawnictwo Naukowe PWN, Warszawa 2007, 17-75, 126-139

27. Woynarowska B.: Edukacja zdrowotna - podstawy teoretyczne

i metodyczne [w:] Woynarowska B. (red.).: Edukacja zdrowotna. Podręcznik akademicki. Wydawnictwo naukowe PWN, Warszawa 2008, 15-266

28. Wrześniewski K.: Styl życia a zdrowie: Wzór zachowania A. Wydawnictwo Instytutu Psychologii PAN. Warszawa 1993

29. Wysocki M.J., Miller M.: Paradygmat Lalondea. Światowa Organizacja Zdrowia i nowe zdrowie publiczne. Przegląd Epidemiologiczny 2003, 505-512

30. Ziemlański S.: Podstawy prawidłowego żywienia człowieka. Zalecenia żywieniowe dla ludności w Polsce. Instytut Danone. Fundacja Promocji Zdrowego Żywienia, Warszawa 1998

Address for correspondence: e-mail:klreh@cm.umk.pl

Received: 10.11.2015

Accepted for publication: 23.03.2016 